\title{
Unusual Length of the Ac-Pc Line and the Importance of Direct Targeting
}

\author{
Ümit Akin Dere ${ }^{1 *}$, Mehmet Tönge², Yasin Temel ${ }^{3}$ and Ersoy Kocabıçak ${ }^{4}$ \\ ${ }^{1}$ Department of Neurosurgery, Mehmet Akif İnan Research Hospital, Turkey \\ ${ }^{2}$ Department of Neurosurgery, Memorial Hospital, Turkey \\ ${ }^{3}$ Department of Neurosurgery and Neuroscience, Maastricht University Medical Center, The Netherlands \\ ${ }^{4}$ Department of Neurosurgery, Ondokuz Mayıs University Medical School, Turkey
}

Submission: October 24, 2016; Published: November 05, 2016

*Corresponding author: Ümit Akın Dere, Department of Neurosurgery, Mehmet Akif İnan Research Hospital, Sanlıurfa, Turkey, Tel: +90-414318-60-00, +90-532-698-26-06; Fax: +90-414-318-68-20; Email: umitakindere@gmail.com

\section{Introduction}

Deep brain stimulation (DBS) of the subthalamic nucleus (STN) is a widely performed surgical procedure for patients with advanced Parkinson's Disease (PD) [1]. Anatomically, the STN is a small brain area located in the junction between the diencephalon and midbrain $[2,3]$. Therefore, it is not always easy to localize. While the STN was not visible on routine clinical magnetic resonance imaging (MRI) in the beginning of the modern DBS era, it became a structure which could be shown clearly on T2 weighted MRI $[3,4]$. These advances in MRI technology has resulted in a change from atlas-based targeting to direct targeting. In our centers, we apply the atlas-based coordinated to the T2W MRI and adjust the coordinates for the individual patient to be able to target the dorsolateral part of the STN, which is considered as the motor part [5]. Today, we know that, some DBS centers aren't able to use advance MRI techniques yet. Additionaly, some of them may not want to use direct targeting because they believe their own techniques strongly for DBS surgery which includes indirect targeting and intraoperative microelectrode recording. Key anatomical landmarks for atlasbased targeting are the anterior and posterior commissure (AC and PC). The midpoint of the intercomissural line is the reference ("zero point"). The usual lenght of the AC-PC line is measured

between 19 to $32 \mathrm{~mm}$ in the majortiy of the procedures [6-8]. Here, we report a case who performed DBS of the STN for PD with an unusual high length of the AC-PC line.

\section{Case}

Fifty-one years old female who wasan akinetic-rigid PD patient for 10 years referred to our clinic for DBS surgery. Brain MRI showed, ventriculomegaly, without any clinical signs of hydrocephalus. After routine screening, which included neurophysiological and pschyiatric examinations, the patient was considered good candidate for DBS of the STN.

\section{Surgery}

A preoperative MRI was performed consisting of contrast enhanced T1-weighted and T2-weighted images. Anterior and posterior commissures were identified and AC-PC line was calculated. The measured length of the AC-PC line was $33.17 \mathrm{~mm}$. This was interestingly long which had never been reported before in DBS surgery as far as we know. We pointed dorsolateral part of the STN on T2 weighed axial MR images using direct targeting method. Surgery was performed under local anesthesia. After making a precoronal burr hole, micorecording electrodes were introduced. The burr-hole is covered by cottonoids to prevent substantial cerebrospinal fluid (CSF) leackage. Recordings were performed in steps of $0.5-1 \mathrm{~mm}$, from $10 \mathrm{~mm}$ above the presumed target until 4 or $5 \mathrm{~mm}$ below target with microelectrodes (Leadpoint@Medtronic Inc). The STN was characterized by a neuronal firing pattern consisting of increased baseline activity and a strong increase of high-voltage spikes, which was usually present over a length of 1-8 $\mathrm{mm}$. After evaluation length of the recordings and observed therapeutic and side effects by test stimulation, permanent electrode implanted in central trajectory and first pole of the lead was located at $3 \mathrm{~mm}$ below the target on the first side (left). The same procedure was used on the second side. But, permanent electrode was implanted in same trajectory but first pole of the lead was located at 1,5 $\mathrm{mm}$ below the targeton this side (right). One day later, the second operation was performed under general anesthesia, to implant the pulse generator infraclavicularly (Activa PC, Medtronic).

\section{Discussion}

DBS of the STN has become a routine surgical therapy for patients with PD. The planning and surgical part of this 


\section{Open Access Journal of Neurology \& Neurosurgery}

procedure has been refined during the years [9]. One of the advances that have contributed substantially to the success of DBS surgeries is improved MR imaging techniques and its availability. This has shifted the field from indirect to direct targeting $[4,10]$. This case would have been difficult for accurately determine the motor part of the STN, if the old MRI techniques with atlas based coordinates -also known indirect targeting- were used for preoperative planning. Recently, with the improving MRI techniques, especially in T2 weighted images, the STN has become aclear visualization [11]. Indirect targeting is based on standardized stereotactic atlas and on a formuladerived method based on AC-PC landmarks. Widely accepted stereotactic coordinates of the dorsolateral part of the STN, also known motor part, according to the midcommissural point (MCP) are 11-13 mm lateral to the AC-PC line, 3-5 mm ventral and 2-3 $\mathrm{mm}$ posterior to the MCP $[12,13]$.

However in our case, the above-mentioned coordinates did not localize the motor part of the STN which is located dorsolaterally when we compared on the T2 weighted MR images. For that reason, we changed the coordinates in direct planning on MRI.In our surgical technique, we use cottonoids to prevent the CSF leackage for microelectrode recordings [5]. However, it is known that a little CSF leackage can't be prevented despite all the precautions, especially on the second side of the surgery. Therefore some authors advocate the usage of microelectrode recording for find the STN because of this reason. Furthermore, the risk of CSF leackage was probably higher because of ventriculomegaly in our case.

\section{Conclusion}

In conclussion, we suggest the usage of direct targeting for preoperative planning and intraoperative MER for DBS surgery in order to localize the motor part of the STN accurately, especially on extreme cases like this.

\section{References}

1. Odekerken VJ, Laar TV, Staal MJ, Mosch A, Hoffmann CF, et al. (2013) Subthalamic nucleus versus globus pallidus bilateral deep brain stimulation for advanced Parkinson's disease (NSTAPS study): a randomised controlled trial. Lancet Neurol 12(1): 37-44.
2. Camlidag I, Kocabicak E, Sahin B, Jahanshahi A, Incesu L, et al. (2014) Volumetric analysis of the subthalamic and red nuclei based on magnetic resonance imaging in patients with Parkinson's disease. International Journal of Neuroscience 124(4): 291-295.

3. Temel Y, Blokland A, Steinbusch HW, Vandewalle VV (2005) The functional role of the subthalamic nucleus in cognitive and limbic circuits. Prog Neurobiol. 76(6): 393-413.

4. Tonge M, Kocabicak E, Ackermans L, Kuijf M, Temel Y, et al. (2015) Final electrode position in subthalamic nucleus deep brain stimulation surgery: a comparison of indirect and direct targeting methods. Turk Neurosurg.

5. Andrade-Souza YM, Schwalb JM, Hamani C, Eltahawy H, Hoque T, et al. (2005) Comparison of three methods of targeting the subthalamic nucleus for chronic stimulation in Parkinson's disease. Neurosurgery 56(2Supl): 360-368.

6. GuehlD, Edwards R, Cuny E, Burbaud P, Rougier A, etal. (2007) Statistical determination of the optimal subthalamic nucleus stimulation site in patients with Parkinson disease. J Neurosurg 106(1): 101-110.

7. Lanotte MM, Rizzone M, Bergamasco B, Faccani G, Melcarne A, et al. (2002) Deep brain stimulation of the subthalamic nucleus: anatomical, neurophysiological, and outcome correlations with the effects of stimulation. J Neurol Neurosurg Psychiatry 72(1): 53-58.

8. Lee TO, Hwang HS, Salles AD, Mattozo C, Pedroso AG, et al. Inter-racial, gender and aging influences in the length of anterior commissureposterior commissure line. J Korean Neurosurg Soc 43(2): 79-84.

9. Kocabicak E, Temel Y (2013) Deep brain stimulation of the subthalamic nucleus in Parkinson's disease: surgical technique, tips, tricks and complications. Clin Neurol Neurosurg 115(11): 2318-2323.

10. Kocabicak E, Alptekin O, Ackermans L, Kubben P, Kuijf M, et al. Is there still need for microelectrode recording now the subthalamic nucleus can be well visualized with high field and ultrahigh MR imaging?. Front Integr Neurosci 9: 46.

11. Plantinga BR, Temel Y, Roebroeck A, Uludağ K, Ivanov D, et al. Ultrahigh field magnetic resonance imaging of the basal ganglia and related structures. Front Hum Neurosci 8: 876

12. Machado A, Rezai AR, Kopell BH, Gross RE, Sharan AD, et al. (2006) Deep brain stimulation for Parkinson's disease: surgical technique and perioperative management. Mov Disord 21(14Supl): S247-S258.

13. Starr PA, Christine CW, Theodosopoulos PV, Lindsey N, Byrd D, et al. Implantation of deep brain stimulators into subthalmic nucleus: technical approach and magnetic imaging-verified electrode locations. J Neurosurg 97(2): 370-387.

\section{Your next submission with JuniperPublishers} will reach you the below assets

- Quality Editorial service

- Swift Peer Review

- Reprints availability

- E-prints Service

- Manuscript Podcast for convenient understanding

- Global attainment for your research

- Manuscript accessibility in different formats

( Pdf, E-pub, Full Text, Audio)

- Unceasing customer service

Track the below URL for one-step submission http://juniperpublishers.com/online-submission.php 